\title{
A SYSTEMATIC STUDY REGARDING THE IMPORTANCE OF OBTAINING ECOLABEL IN ROMANIA
}

\author{
ANTONINA TEMEA ${ }^{1 *}$, VALENTIN NEDEFF ${ }^{1}$, CLAUDIO COMOGLIO ${ }^{2}$, \\ SERENA BOTTA ${ }^{2}$, MIRELA PANAINTE-LEHADUS ${ }^{1}$ \\ ${ }^{1}$ Department of Environmental Engineering and Mechanical Engineering, ,, Vasile \\ Alecsandri" University of Bacau, Street Marasesti 157- 600115 Bacau, Romania \\ ${ }^{2}$ DIATI, Politecnico di Torino, Corso Duca degli Abruzzi 24 - 10129 Torino, Italy
}

\begin{abstract}
The purpose of this paper is to review and present a short synthesis of the scientific literature on Ecolabel and an analysis of the types of products and services in Romania that obtained this environmental label. European eco-label is the only environmental quality label (type I; ISO 14024), awarded at institutional level (EC) valid all around the Europe, and it represents a unique opportunity to satisfy consumer expectations. In this way is promotes the design, production and marketing of products with lower environmental impact during their entire life cycle compared to other products in the same category. The EU Ecolabel covers a wide range of product groups, from major areas of manufacturing to tourist accommodation services. Key experts, in consultation with main stakeholders, develop the criteria for each product group in order to decrease the main environmental impacts over the entire life cycle of the product. Because the life cycle of every product and service is different, the criteria are tailored to address the unique characteristics of each product type. The European Ecolabel was introduced in Romania in 2002.
\end{abstract}

Keywords: ecolabel, environmental impact, life cycle, Romania

\section{INTRODUCTION}

Environmental labels and declarations are at the crossroads of environmental concerns and commerce. Voluntary ecological labelling is the result of a business approach which aims to take advantage of market forces to influence the informed consumer [1] and to carve out a prime position in a potentially profitable market niche. Voluntary ecolabelling also serves as a means of regulation through consumer information, and thus is part of the third wave of sustainable development tools [2].

Green labeling or eco-labeling started, about 43 - 44 years ago, in 1970 by placing green stickers on consumer goods. In the late 1980s the Canadian government launched EcoLogo labeling system [3]. The Nordic Swan Ecolabel was established in 1989 by the Nordic Council of Ministers with the purpose of providing an environmental labelling scheme that would contribute to a sustainable consumption. The Nordic Swan Ecolabel was also initiated as a practical tool for consumers to help them actively choose environmentally products [4]. In 1992, after the Earth Summit of the United Nations, the European Union initiated the Ecolabel, wearing a flower as a symbol [3].

\footnotetext{
${ }^{*}$ Corresponding author, email: ninatemea@yahoo.com

(c) 2016 Alma Mater Publishing House
} 
In Romania eco-label is awarded on request, groups of products / services that have high potential for environmental protection, owning advantages beneficial to manufacturers of products and / or service providers and have high demand for consumer manifested by sales volume [5].

In the year 2015, Romania has 24 eco-labels, however is still very low compared to many other countries, especially European [6].

ISO later proposed three categories of environmental labels according to the aspects covered and the rigor required to award the seal: type I in ISO 14024; type II in ISO 14021; and type III in ISO 14025 [7]. Additionally, a different category called "Type I e like" is present in the literature, which represents environmental labels focused only one environmental or social aspect, these labels have been launched by independent organizations [6].

In the last time it can be noted a growing interest of organizations to protect the environment and for environmental issues [8]. System implementation of environmental management began a major concern for many organizations. A growing number of certifications for environmental management systems was registered in countries such as Japan or China [9].

The number of certifications annually increase, and the main reason is the desire of organizations to increase their environmental performance [8].

The consumers play an important role in the protection of environment by their choices when they purchase products [10]. Consequently, with a view to manufacture products with minimum impact on environment as well as to influence the conduct of consumers and improve the ecological performance of products and services, the ISO 14000 standards were elaborated for ecological labelling and analysis of life cycle of products and national and regional systems of ecological labelling of products were introduced [11].

Obtaining the eco label is not mandatory and any request for its grant is subject to the payment of a fee and consequently the economic agent who has been awarded with the European eco label must pay an annual fee for its use (Table 1) [12].

Table 1. How much does it cost? [12].

\begin{tabular}{|c|c|c|c|}
\hline Fees & Minimum & Maximum & Reductions \\
\hline $\begin{array}{c}\text { Application fee covers } \\
\text { the costs of } \\
\text { processing the } \\
\text { application }\end{array}$ & EUR 200 & EUR 1200 & $\begin{array}{c}\text { Max. EUR 600 for SMEs and applicants from } \\
\text { developing countries Max. EUR 350 for micro- } \\
\text { enterprises 20\% reduction for companies registered } \\
\text { under EMAS or certified under ISO 14001 }\end{array}$ \\
\hline $\begin{array}{c}\text { Annual fee for the use } \\
\text { of the Ecolabel equals }\end{array}$ & $/$ & EUR 1500 & $\begin{array}{c}\text { Max. EUR 750 for SMEs and applicants from } \\
\text { developing countries Max. EUR 350 for micro- } \\
\text { enterprises }\end{array}$ \\
\hline
\end{tabular}

\section{THE ECO-LABEL IN EUROPE}

In an attempt to discover research gaps and select the most relevant studies from which to infer the current state of ecolabels in Romania, I chose the systematic literature review as an appropriate method for carrying out this study. It was carried out a research regarding the attitude of Romanian consumers related to the ecological products [11].

In September 2016, there were 36,395 products that were awarded EU Ecolabel. The countries with most EU Ecolabel licenses were France (26\%), Italy (18\%), and Germany (12\%). EU Ecolabel has a strong position in most of the European countries and other ecolabelling schemes are triggered to take a position concerning the overlap with EU Ecolabel, for example Nordic ecolabel that in the Nordic countries is more popular than EU Ecolabel. In Germany, the Blue Angel is very common [13].

In a 2013 survey, Denmark was shown to be the top country in Europe where consumers recognize the EU Ecolabel and know what it stands for, with $35 \%$ of consumers recognizing it visually and $17 \%$ of consumers knowing its meaning [13]. 
The paper present the results of a research performed in 2014 by the European Union on environmental issues in Romania (Barometer 85, years 2011-2014). The survey, published in May 2014, was conducted on a sample of 1,062 respondents in Romania and 27,998 respondents in EU 28 [13].

For population from Romania the importance of environmental protection is very important (51\%), and very important (40\%), with very little difference to the EU 28 (with $2 \%$ smaller than European average) [13].

The eco-labels developed by the Nordic Swan and the Swedish Environmental Choice include requirements which address the whole life-cycle of the product. Eco-labels have been developed by these schemes for various types of detergents, cleaning agents, paper products, etc. which have had a heavy market impact and include production related criteria. Producers, both domestic and foreign, have modified their processes and production methods to meet the eco-label criteria and maintain their products on the market [8].

The general public, in this case the ultimate consumer of the goods or services does not have at its disposal enough information. In general, the fact that one company or another holds certifications of ISO series does not affect the perception of the goods, services in the purchase decision [8]. Instead, companies should certify and make this known. Should promote the quality of products or services, with the message that they are responsible companies that respect the environment and make efforts to continually improve internal processes [5].

Consumers are conscious about the usage of green products and its importance and favorable consequences on the environment. Still there are persons who can only think about their own health and who did not understand the real role they are playing [9].

If we want to support real development production products eco-labeled as a means of obtaining profit, we must not only respect legal norms, but to be one step ahead by studying consumers and understanding their wishes and offer the best solutions to choose eco-labeled products [1].

\section{THE CURENT STATE OF ECO-LABEL IN ROMANIA}

The Romanian law defines the ecolabel as "a graphic symbol or short textual product description applied on products or which is to be found in a brochure or other informative document which accompanies the product and which provides information on maximum three types of impact on the environment generated by the product or service in cause" [9].

The current market environment does not allow the organization making decisions without previous investigating environment in which it operates, as consumer demands evolve in an accelerated way, competition is increasingly fierce, and the elements of macroeconomic and legislative can have influence over success or failure of the company on the market [7]. Any decision on the organization's work must be based on concrete data on the size and components of the organization's marketing environment, so that products and / or services provided by this is in line with market requirements [9].

The analysis of study "Barometer 85" show that main goals of the Ecolabelling are pollution prevention and strengthening of the environmental protection, support and promotion of production and consumption, with reduced negative influences on the environment, strengthening of consumers environmental awareness regarding the environmental properties of products and reduction risk factors in the environment.

Across the EU, a large proportion of citizens $74 \%$ buy eco-labeled products, so are classified into two categories of acquisition: those who buy regularly and those who do occasionally. More than half of respondents are classified as making occasional purchases $(54 \%)$ and another quarter as regularly (26\%). Romania is very close to the European average with $71 \%$ of people who purchase eco-labeled products [13].

In Romania, a percentage of $8 \%$ for respondents indicate that they do not buy environmentally-friendly products and do not intend to do so.

There is near unanimous agreement on the ethics of environmentally-friendly products. For Romania, $97 \%$ of respondents agree that using environmentally products is 'the right thing to do', $94 \%$ agree that buying 
environmentally-friendly products sets a good example and $92 \%$ agree that their family and friends would think it was a good thing if they used environmentally-friendly products (with $2 \%-12 \%$ higher than European average).

Most people are willing to consider environmental factors when making purchases, but few they feel fully informed about these issues.

A percentage of $97 \%$ of Romanian respondents believe that the purchase of environmentally friendly products is the right thing that they have to do it and $94 \%$ think this is a good example.

By purchasing green products can help protect the environment, believe $95 \%$ of respondents while $92 \%$ say family and friends agree that is a good thing to buy these products.

Slightly more than half of Romanian citizens think that environmentally-friendly products are easily available in shops (64\%), $32 \%$ disagreeing, with $10 \%$ higher than European average. A similar proportion of Romanian citizens believe that it is easy to differentiate environmentally-friendly products from other products ( $76 \%), 22 \%$ disagreeing with $25 \%$ higher than European average.

\section{CONCLUSIONS}

Given the fact that Romania is presented yet timid progress in increasing environmental performance, we believe that sustained progress on line environment should be a priority for all Romanian organizations. Leaving aside the obligation to comply with the requirements of EU which should not be overlooked companies must perceive the advantages to be gained by implementing EMS, such as ISO 14001, EMAS and Ecolabel. These actions are also necessary to give to the system an increased degree of attractively for producers and traders.

To be credible and to develop as added value for the customer in the conditions of affordable services entire infrastructure of conformity assessment from Romania should practically apply the principles it promote: customer orientation, taking into account the interests of all stakeholders, transparency in the functioning and decisionmaking mechanisms, correlation tariffs and offers with real customer requirements from Romania, ongoing assessment of customer satisfaction and establish appropriate corrective and preventive actions in a timely manner. Only by such methods, we can have in Romania a business environment that is sufficiently homogeneous, transparent and credible so that they can trust him both public authorities and, especially, businesses and consumers from our country.

The reasons for which Romanian economic operators are not interested in eco-labelling their products reside, mainly, in the voluntary character of European eco-label (consequently, the economic units do not have the obligation to apply the eco-label on their products) and in the fact that the use of ecological label determines the increase of the price of eco-labelled product, which would induce the fear of sales' reduction.

The utility of this study is reflected in the outcome research highlighting Romania's position among the lowest countries in the adoption of ecolabel, which allows new perspectives for research towards the design and adoption of measures to remedy the current situation.

For future research, the index provides a relative measure of ecolabel products over time and it can be used for comparisons across areas and over time. In addition, in the future, Romania should adopt a policy of eco-innovation to solve problems that arise in relation to: the failure of market prices (prices should reflect significant cost and environmental benefits), obstructionist behavior regarding the introduction of eco-innovation, rigid economic structures towards the adoption of eco-innovation, harmful incentives and subsidies, and infrastructure.

\section{REFERENCES}

[1] Case, D.W., The law and economics of environmental information as regulation, E.L.R., Washington, D.C., vol. 7, 2001, p. 10773-10789.

[2] Sinclair, D., Gozian, E., A theory of environmental risk disclosure. Journal of Environmental Economics and Management, vol. 45, 2003, p. 377-393. 
[3] Boztepe, A., Green marketing and its impact on consumer buying behavior, European Journal of Economic and Political Studies, vol. 5, 2012, p. 5-21.

[4] Amyx, D.A., Dejong, P.F., Lin, X., Chakraborty, G., Weiner, J.L., Influencers of purchase intentions for ecologically safe products: an exploratory study, AMA Winter Educators' Conference Proceedings. American Marketing Association, Chicago. IL, vol. 5, 1994, p. 341-347.

[5] Vanessa, P. S, Jose, A., Andres, M.V., Marta, O., ECO-labels as a multidimensional research topic: Trends and opportunities, Journal of Cleaner Production, vol. 135, 2016, p. 806-818.

[6] Olaru, M., Responsible commercial activity of SMEs and specific values of sustainable development in terms of the european excellence model. Amfiteatru Economic, vol. 11, no. 27, 2010, p. 10-26.

[7] Morar, A., Rada, B., Eco-marketing research in Romanian firms for the availability of introducing products friendly to the environment on the market, Agricultura - Stiinţa si practica, 2011, p. 77-78.

[8] Leire, C., Thidell, A., Product-related environmental information to guide consumer purchases e a review and analysis of research on perceptions, understanding and use among Nordic consumers, Journal of Cleaner Production, vol. 10, 2005, p. 1061-1070.

[9] Panainte, M., Inglezakis, V., Caraman, I., Nicolescu, M.C., Mosnegutu, E., Nedeff, F., 2014. The evolution of eco-labeled products in Romania, Environmental Enginering Management Journal, vol. 7, 2014, p. 1665-1671.

[10] Comanescu, M., Increasing Responsibility towards Environment, Theoretical and Applied Economics, vol. 17, no. 5, 2010, p. 59-72.

[11] Dinu, V., Schileru, I., Atanase, A., Attitude of Romanian consumers related to products' ecological labelling, Amfiteatru Economic, vol. 13, no. 31, 2012.

[12] HG nr. 236 din 07/03/2000, privind stabilirea unor masuri pentru asigurarea aplicarii Regulamentului Parlamentului European si al Consiliului nr. 1980/2000/CE din 17 iulie 2000 privind sistemul revizuit de acordare a etichetei ecologice comunitare. Monitorul Oficial, nr. 184 din 16/03/2007.

[13] Flash Eurobarometer 367, Attitudes of europeans towards building the single market for green products report, Fieldwork: December 2012 Publication: July 2013. 